\title{
A new species of the genus Aphanisticus (Coleoptera: Buprestidae: Agrilinae) from Indonesia
}

\author{
Mark Yu. KALASHIAN \\ Scientific Center of Zoology and Hydroecology NAS RA, P. Sevak str., 7, Yerevan 0014, Armenia; e-mail: mkalashian1@gmail.com
}

\author{
Accepted: \\ $6^{\text {th }}$ September 2019
}

Published online:

$12^{\text {th }}$ September 2019

\begin{abstract}
Aphanisticus hajeki sp. nov. (Coleoptera: Buprestidae: Agrilinae) from Kalimantan, Indonesia belonging to the Aphanisticus javaecola Obenberger, 1932 species-group, is described and illustrated. Neotype of Aphanisticus bohaci Obenberger, 1924, belonging to the same species-group, is designated. Key to the species of the Aphanisticus javaecola species-group is given.
\end{abstract}

Key words. Coleoptera, Buprestidae, Aphanisticus, new species, neotype designation, taxonomy, Indonesia, Oriental Region

Zoobank: http://zoobank.org/ urn:lsid:zoobank.org:pub:AA8674C3-B67E-43E3-B8BF-EAAF430600E3

(C) 2019 The Authors. This work is licensed under the Creative Commons Attribution-NonCommercial-NoDerivs 3.0 Licence.

\section{Introduction}

The present paper is a further part of my study on the genus Aphanisticus Latreille, 1810 (Kalashian 1993, 1994, 1996, 1999, 2003, 2004, 2005; KuBÁŇ \& KaLASHIAN 2006; KalASHiAn \& KuBÁŇ 2014, 2016). Due to the kindness of Dr. J. Hájek and V. Kubán̆ (NMPC) I have had the possibility to study further material of the genus recently collected in the Oriental Region by my Czech colleagues. Among the specimens a small series of an undescribed species of the genus Aphanisticus belonging to the A. javaecola Obenberger, 1932 species-group was found. Description of this species is given below. Besides, for the sake of stability of nomenclature and for the exact definition of the species, the neotype is designated for $A$. bohaci Obenberger, 1924 belonging to the same species-group. Key to the identification of the species of $A$. javaecola group is given.

\section{Material and methods}

In citations of labels below the following abbreviations are used: [h] - handwritten, [p] - printed; lines as they appear in each label are separated by a slash '/' and data of different labels are separated by a double slash '//'.

The following acronyms of collections are used in the text:

BMNH The Natural History Museum, London, United Kingdom;

MKCY Mark Kalashian's collection, Yerevan, Armenia;
MNHN Museum National d'Histoire Naturelle, Paris, France;

NMPC National Museum, Prague, Czech Republic;

USNM Smithsonian National Museum of Natural History, Washington, D.C., USA;

ZIN Zoological Institute of RAS, Sankt Petersburg, Russia.

\section{Taxonomy}

Aphanisticus hajeki sp. nov. (Figs 1, 4)

Type locality. Indonesia, E Kalimantan, ca. $15 \mathrm{~km} \mathrm{~N}$ of Balikpapan, Sungai Wain Protection Forest, $1^{\circ} 08.1^{\prime} \mathrm{S} 116^{\circ} 49.9^{\prime} \mathrm{E}, 35 \mathrm{~m}$ a.s.1.

Type material. HоLотуре: (NMPC), 'INDONESIA, E Kalimantan / ca. $15 \mathrm{~km}$ N of Balikpapan / Sungai Wain Protection Forest / 01 ${ }^{\circ} 08.1^{\prime} \mathrm{S}$ 116²9.9'E, 35 m / J. Hajek, J. Schneider \& / P. Votruba leg. 8-11. xii.2011 [p] // primary rainforest, individual / in stream, puddles and / swamp, on vegetation and dead / wood; light trap at border of forest [p] // HOLOTYPE / Aphanisticus / hajeki sp. nov. / M. Kalashian det., 2018'. PARATYPES: $2 \delta 3$ 우, the same data as in holotype (NMPC, MKCY).

Description. Body flattened, moderately elongate, 2.903.05 times as long as wide, black with indistinct bronzy luster, surface microreticulated, reticulation rather distinct dorsally, in abdominal ventrites smoothed, nearly invisible. Length $3.10-3.85 \mathrm{~mm}$ (holotype $-3.20 \mathrm{~mm}$ ), width 1.03-1.32 mm (holotype - $1.07 \mathrm{~mm}$ ) (Fig. 1).

Head moderately wide, with sides very feebly arcuate, subparallel. Eyes large, rather convex, well visible from above. Oculofrontal margins sharp, keel-shaped. Frons very slightly widened posteriorly (to above in frontal view), 

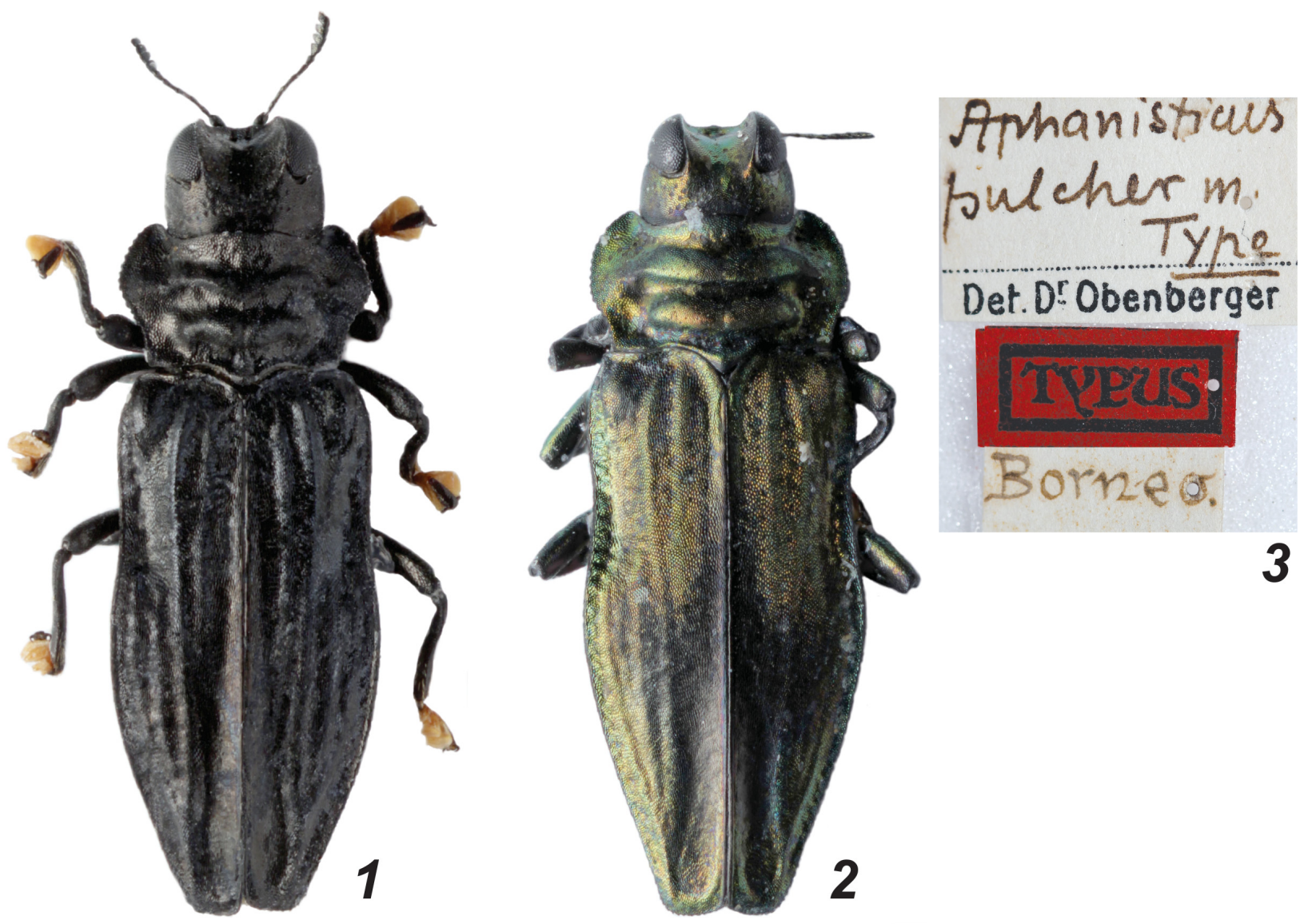

Figs. 1-3. Aphanisticus spp. 1 - A. hajeki sp. nov., holotype, habitus; 2 - A. bohaci Obenberger, 1924, neotype, habitus; 3 - A. bohaci Obenberger, 1924, neotype, labels

with deep doubled postclypeal fovea. Frontovertex deeply concave, concavity rounded posteriorly, not reaching anterior margin of pronotum. Surface of frons anteriorly nearly glabrous, concavity posteriorly with traces of few small punctures, vertex with sparse flat rounded punctures. Antennae serrate from antennomere 8 . Antennomeres 1 and 2 robust, swollen, 3-7 rather long and thin, very finely enlarged distally, antennomere 8 nearly equilateral, 9-11 strongly transversal.

Pronotum 1.55-1.65 times as wide as long, widely cordiform, widest approximately in middle, sides anteriorly nearly regularly arcuate, slightly sinuate before obtuse posterior angles; anterior margin slightly bisinuate, posterior margin bisinuate with moderately wide triangular medial lobe. Lateral margins very finely irregularly serrate. Pronotum narrowly flattened along lateral margins, anterior and posterior margins distinctly elevated, disc with two transverse elevations; anterior elevation with edge obtusely keel-shaped, in shape of tick, posterior nearly completely divided by deep longitudinal groove into pair of irregularly ellipsoidal transverse elevations with rounded edge. Surface with few nearly indistinct traces of small punctures. Scutellum very small, triangular.

Elytra 1.95-2.10 times as long as wide, slightly widened just behind humeri, then sides sinuate approximately to posterior $2 / 5$, where elytra become widest, then first finely arcuately and then nearly straightly narrowed towards slightly, separately angularly rounded apices, which are very finely serrate. Elytra weakly convex, distinctly depressed along suture, narrowly flattened along sides, with fine lateral carina. Humeral callosities with arcuate keel-shaped external edge. Suture entirely keel-shaped. Each elytron with distinct, slightly sinuous, longitudinal, medial keel, distally curved along apex and fusing with suture. Another, less pronounced, longitudinal keel between suture and medial keel in about $3 / 5$ of elytra, and two slightly incurved keels extending from approximately $1 / 5-1 / 6$ of medial keel towards elytral base along lateral sides of elytra. Surface laterally and basally with few indistinct irregular transversal wrinkles and fine punctures, distally and medially this sculpture nearly indistinct.

Propleurae microreticulated, medial portion of sternum and basal portion of abdomen with very shallow and indistinct large irregular punctures, backwards completely smoothed. Anal ventrite in both sexes rather widely, almost straightly truncate, with rounded lateral angles, with posterior margin in male glabrous, in female with very small teeth.

Aedeagus finely sclerotized, rather short and wide, parameres with two angularly rounded lateral lobes distally, penis tube short, approximately 2 times as short as parameres (Fig. 4).

Differential diagnosis. The new species belongs to the $A$. javaecola species-group which is characterized by deeply 


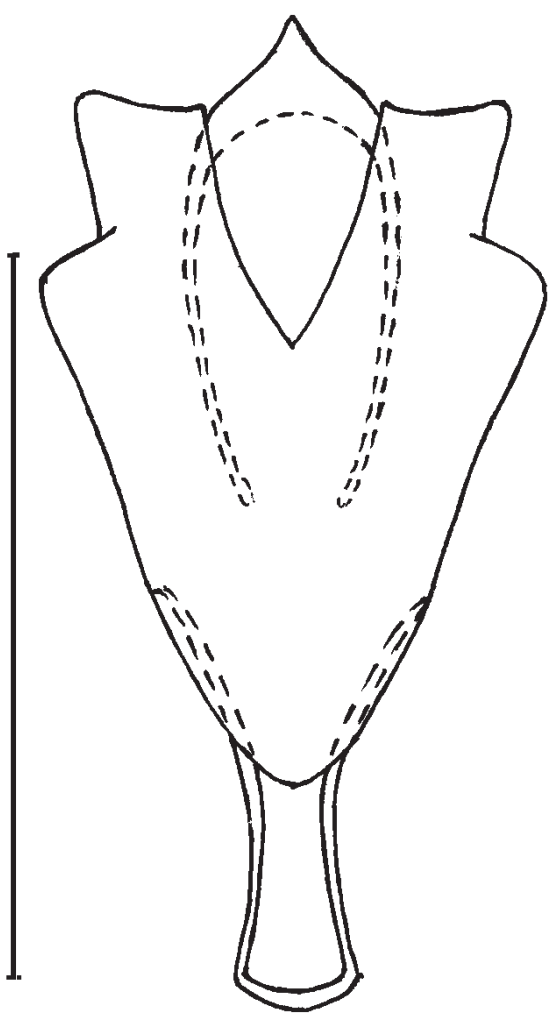

Fig. 4. Aphanisticus hajeki sp. nov., aedeagus. Scale bar $=0.25 \mathrm{~mm}$.

concave frontovertex, rather convex eyes well visible from above, two broad transverse elevations on pronotum, and by presence of distinct longitudinal elytral costae. Aedeagus of the species of the group is rather short and wide. Aphanisticus javaecola species-group can be distinguished from other groups of Aphanisticus with costate elytra, occurring in the East Palaearctic and Oriental Regions, using the key provided in Kalashian (2004). To distinguish the new species from other species belonging to this group see the key below.

Etymology. The new species is dedicated to one of its collectors, Dr. Jiří Hájek (NMPC), with my gratitude and respect.

\section{Aphanisticus bohaci Obenberger, 1924} (Figs 2-3)

Type material. NeOtyPE (designated here): sex unknown (NMPC), 'Borneo [h] // Typus [p, on red paper] // Aphanisticus pulcher m. / Type [h] /

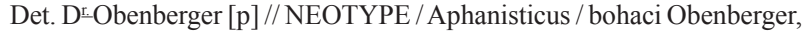
1924 / M. Kalashian design., 2018'.

Remarks. Aphanisticus bohaci belongs to A. javaecola species-group. It was described in the large work by OBENBERGER (1924) dedicated mainly to the Buprestidae collected by Ch. F. Baker in Singapore, Borneo and the Philippines but the other material from Obenberger's collection was used as well. The majority of the types of the species described in this work are deposited in USNM and some in NMPC. However, there are no type specimens bearing the name $A$. bohaci in either of the collections. Besides searching in the collections mentioned above I tried to find the type specimen(s) of $A$. bohaci in the other collections where some Obenberger's types could be deposited, including BMNH, ZIN, MNHN but with no success. On the other hand, there is a specimen in NMPC which fully corresponds to the description of $\mathrm{A}$. bohaci [OBEnBerger (1924): 621 (key), 623 (description), Plate 1:7]. This specimen (Fig. 2) is designated as a type, but bears the identification label "Aphanisticus pulcher m." (Fig. 3), the name which was never published by Obenberger. Most probably, Obenberger changed his mind concerning the name of the species but did not change the labels accordingly; however, this assumption cannot be proved. To remove the doubts about the identity of Aphanisticus bohaci Obenberger, I designate the 'type' of $A$. pulcher as the neotype of $A$. bohaci according to the Articles 75.1 and 75.3 of the International Code of Zoological Nomenclature (ICZN 1999). The type specimen is card mounted, its condition good, no damage was registered. The type locality of the species corresponds to its description: "Borneo [Island]" without indicating the state (it is well known that Obenberger removed original labels replacing them with his own handwritten labels, and thus it is impossible to give any precise geographical data). The neotype designation is necessary for the exact definition of the species for further study of this rather complicated species-group.

\section{Key to the species of Aphanisticus javaecola species-group}

1(8) Pronotum with two transverse elevations entirely separated from each other by deep, nearly even transverse depression.

2(5) Anterior elevation of pronotum with slightly incurved anterior and nearly straight posterior margins, both elevations with rounded edges.

3(4) Body olive green. Body length $3.42 \mathrm{~mm}$. Borneo. . A. bohaci Obenberger, 1924

4(3) Body black, pronotum with very weak bronzy reflection, elytra with indistinct steel or greenish luster. Body length 3.30-3.55 mm. Malaysia (Perak, Sabah), Indonesia (Sumatra).

A. viti Kalashian, 2004

5(2) Anterior elevation of pronotum with strongly incurved anterior margin, posterior one more or less angularly protruded, both elevations with obtusely keel-shaped edges.

6(7) Transverse elevations of pronotum less pronounced, posterior one nearly entire, only slightly depressed in middle. Elytral costae narrower, crisper. Body slender, 3.40 times as long as wide, elytra 2.40 times as long as wide. Bigger, body length $5.00 \mathrm{~mm}$. Borneo.

A. corniceps Obenberger, 1924

7(6) Pronotal transverse elevations stronger, posterior one nearly completely divided by rather deep and narrow longitudinal groove. Elytral costae wider and less crisp. Body moderately elongate, 2.90-3.05 times as long as wide, elytra 1.95-2.10 times as long as wide. Smaller, body length $3.10-3.85 \mathrm{~mm}$. Indonesia (E Kalimantan). A. hajeki sp. nov. 
8(1) Transverse elevations of pronotum joined in middle by longitudinal elevation, pronotum with deep and wide foveae from both sides of this longitudinal elevation.

9(10) Body slender, 3.05 time as long as wide. Transverse elevations of pronotum flattened, joining longitudinal elevation wider. Body length $3.90 \mathrm{~mm}$. Philippines (Luzon). ........ A. costipennis Fisher, 1921

10(9) Body wider, less than 2.85 time as long as wide. Transverse elevations of pronotum more convex, joining longitudinal elevation narrower.

11(12) Elytral surface between costae without macrosculpture, only densely microreticulated, with silky luster. Body length 2.95-4.15 mm. Malaysia (Tioman Island).

A. lubopetri Kalashian, 2004

12(11) Elytral surface between costae with irregular transverse wrinkles, microreticulation very delicate, surface shiny.

13(14) Transverse elevations of pronotum with rather sharp keel-shaped edges. Foveae separating these elevations more rounded. Body length 2.95-3.00 $\mathrm{mm}$. Indonesia (Java, Sumatra).

A. javaecola Obenberger, 1932

14(13) Anterior elevation of pronotum keel-shaped, obtuse, posterior one with rounded edge. Foveae separating these elevations more ellipsoidal. Body length 3.30-3.40 mm. N Vietnam.

A. kabakovi Kalashian, 1993

\section{Acknowledgements}

I would like to express my deepest gratitude to Vítězslav Kubáň, Svatopluk Bílý and Jiří Hájek (NMPC) for their hospitality during my stay in beautiful Prague, for continuous help in my work in the National Museum's Buprestidae collection and for providing me with the materials for study.

\section{References}

ICZN 1999: International Code of Zoological Nomenclature. Fourth edition. The International Trust for Zoological Nomenclature, London, 106 pp. Available from: http://www.iczn.org/iczn/index.jsp
KALASHIAN M. YU. 1993: Materialy k faune zhukov-zlatok (Coleoptera, Buprestidae) V'etnama. I. Rod Aphanisticus Latreille. (Material on the fauna of buprestid beetles (Coleoptera, Buprestidae) of Vietnam. I. Genus Aphanisticus Latreille). Entomologicheskoe Obozrenie 72: 601-605 (in Russian, English summary).

KALASHIAN M. YU. 1994: Contribution to the knowledge of the jewel-beetles of Vietnam. II. Addition to the genus Aphanisticus (Coleoptera, Buprestidae). Zoosystematica Rossica 3: 97-98.

KALASHIAN M. Yu. 1996: Dva novykh vida zlatok roda Aphanisticus Latreille (Coleoptera, Buprestidae) iz Tailanda. (Two new species of the buprestid genus Aphanisticus Latreille (Coleoptera, Buprestidae) from Thailand). Entomologicheskoe Obozrenie 75: 307-309 (in Russian, English summary).

KALASHIAN M. Yu. 1999: New species of Aphanisticus and Endelus (Coleoptera: Buprestidae) from South-East Asia. Folia Heyrovskyana 7: 293-300.

KALASHIAN M. Yu. 2003: Novye vidy roda Aphanisticus Latreille (Coleoptera, Buprestidae) iz Yugo-VostochnoyAzii is Filippin. (New species of the genus Aphanisticus Latreille (Coleoptera, Buprestidae) from South-East Asia and Philippines). Euroasian Entomological Journal 2: 119-124 (in Russian, English summary).

KALASHIAN M. Yu. 2004: Novye vidy zlatok roda Aphanisticus Latreille (Coleoptera, Buprestidae) iz Indo-Malayskoy oblasti. (New species of the buprestid genus Aphanisticus Latreille (Coleoptera, Buprestidae) from Indo-Malayan region). Entomologicheskoe Obozrenie 83: 151-162 (in Russian, English summary).

KALASHIAN M. YU. 2005: New species of Aphanisticus Latreille from India and Indonesia (Coleoptera, Buprestidae). Pp. 253-260. In: KONSTANTINOV A., TISHECHKIN A. \& PENEV L. D. (eds): Contributions to systematics and biology of beetles. Papers celebrating the 80th birthday of Igor Konstantinovich Lopatin. Pensoft, Sofia-Moscow, 450 pp.

KALASHIAN M. YU. \& KUBÁŇ V. 2014: New species of Aphanisticus Latreille (Coleoptera, Buprestidae) from Sulawesi and Australia. Pp. 213-218, Pls. 29-30. In: TELNOV D. (ed.): Biodiveresity, biogeography and nature conservation in Wallacea and New Guinea. Vol. 2. Entomological Society of Latvia, Riga, $458 \mathrm{pp}$.

KALASHIAN M. J. \& KUBÁŇ V. 2016: Subtribe Aphanisticina. Pp. 30 [New Acts], 550-552. In: LÖBL I. \& LÖBL D. (eds): Catalogue of Palaearctic Coleoptera. Revised and updated edition. Vol. 3. Scarabaeoidea-Scirtoidea-Dascilloidea-Buprestoidea-Byrrhoidea. Brill, Leiden, Boston, 983 pp..

KUBÁŇ V. \& KALASHIAN M. J. 2006: Tribe Aphanisticini (pars). Pp. 45 [New Acts], 404-406. In: LÖBL I. \& SMETANA A. (eds): Catalogue of Palaearctic Coleoptera. Vol. 3. Scarabaeoidea-Scirtoidea - Dascilloidea - Buprestoidea - Byrrhoidea. Apollo Books, Stenstrup, $690 \mathrm{pp}$.

OBENBERGER J. 1924: A study of the Buprestidae, collected by Charles Fuller Baker in Singapore, Borneo and the Philippine Islands. Philippine Journal of Science 25: 539-660. 